\title{
PERAN ORANG TUA DALAM PERTUMBUHAN SPIRITUALITAS ANAK: SEBUAH STUDI EKSEGETIS EFESUS 6:1-4 \\ Waharman \\ waharman@sttab.ac.id
}

\begin{abstract}
The role of parents for their children in spiritual growth is very important, and starting from an early age, teaching for children's spiritual growth is not only given to the church, or during Sunday school services but the most important and most important is the role of parents in the family for her children. If noted, there are still many parents who do not realize the importance of their role as parents to educate the spiritual growth of their children. Therefore through this paper, we try to remind the important role of parents in the growth of children.
\end{abstract}

Keywords: Role, Parents, Growth, Child Spirituality.

Abstraksi: Peranan orangtua bagi anak-anaknya dalam pertumbuhan rohaninya itu sangat penting, dan dimulai sejak usia dini, pengajaran untuk pertumbuhan rohani anak tidak hanya diserahkan kepada gereja, atau pada saat ibadah sekolah minggu saja tetapi yang terpenting dan yang terutama adalah peran orangtua dalam keluarga untuk anak-anaknya. Jika diperhatikan masih banyak orangtua yang belum menyadari pentingnya peranan mereka sebagai orangtua untuk mendidik pertumbuhan rohani anak-anaknya. Oleh karena melalui tulisan ini mencoba untuk mengingatkan kembali pentingnya peran orang tua dalam pertumbuhan anak.

Kata Kunci: Peran, Orang Tua, Pertumbuhan, Spiritualitas Anak.

\section{PENDAHULUAN}

Alkitab memiliki perhatian besar terhadap pendidikan anak. Sejak Perjanjian Lama, Allah telah mengingatkan pentingnya pendidikan bagi anak-anak. Musa mengingatkan hal ini kepada para orangtua, "Tetapi waspadahal dan berhati-hatilah, supaya jangan engkau melupakan hal-hal yang dilihat oleh matamu sendiri, dan jangan semuanya itu hilang dari ingatanmu.Beritahukanlah kepada anak-anakmu dan kepada cucu cicitmu semuanya itu (Ulangan 4:9)."1 Ungkapan ini merupakan bukti bahwa Allah sangat memperdulikan anakanak.

Amsal juga menuliskan tentang peran orangtua bagi anak-anaknya, hajarlah anakmu selama ada harapan, tetapi jangan engkau menginginkan kematiannya (Amsal

\footnotetext{
${ }^{1}$ Kitab Ulangan 4:9
} 
19:18), Didiklah orang muda menurut jalan yang patut baginya, maka pada masa tuanya pun ia tidak akan menyimpang dari pada jalan itu (Amsal 22:6). ${ }^{2}$

Dalam hal inipun Paulus menarik perhatian, betapa Paulus memikirkan jemaat setempat sebagai "jemaat keluarga". Itu mengingatkan kita kepada kata-kata Tuhan Yesus, "Biarkan anak-anak itu datang kepada-Ku, jangan menghalang-halangi mereka, sebab orang-orang yang seperti itulah yang empunya Kerajaan Allah" (Markus 10:14); dan "Barangsiapa menyambut seorang anak seperti ini dalam nama-Ku, ia menyambut Aku" (Mat 18:5). Ucapan Tuhan Yesus itu sangat berpengaruh, justru Paulus khusus menyebut anak-anak dalam suratnya (Efesus 6:1; Kolose 3:20). Nampaknya, ia mengharapkan anakanak hadir dalam kebaktian jemaat dan mendengar suratnya dibacakan kepada jemaat. Disini Paulus mengingatkan kembali kepada setiap orangtua agar menjalankan setiap tugasnya, berperan aktif untuk perkembangan anak. ${ }^{3}$

Paulus menasihatkan orangtua untuk hidup dalam "ajaran dan nasihat Tuhan”.Artinya ketika orangtua sudah hidup dalam ajaran dan nasihat Tuhan, orangtua dapat mengajarkannya kepada anak-anaknya.Sehingga pengajaran yang diajarkan orangtua kepada anak-anaknya dapat ditangkap dan dilakukan kepada anak-anaknya. ${ }^{4}$

Menurut perkataan Paulus dalam Efesus 6:4 dan Kolose 3:21, dan juga perintah Allah dalam Perjanjian Lama (Kej. 18:19; Ul. 6:7) maka orangtua bertanggungjawab untuk memberi asuhan dan didikan kepada anak mereka yang akan mempersiapkan mereka untuk hidup berkenan kepada Allah. Pendidikan anak itu tanggungjawab bersama, antara orangtua dan gereja, namun yang terutama bertanggungjawab memberikan pendidikan Alkitab dan kerohanian kepada anak-anak adalah keluarga, bukan menyerahkan sepenuhnya kepada gereja atau sekolah minggu.Gereja dan sekolah minggu hanya membantu didikan dari orangtua. Inti pengasuhan Kristen ialah: Hati bapa harus berpaling kepada hati anaknya agar dapat membawa hati anak itu kepada hati Juruselamat. Dalam membesarkan anak-anak mereka, orangtua hendaknya jangan menunjukkan sikap pilih kasih, harus memberi dorongan dan juga teguran, hanya menghukum perbuatan salah yang dilakukan dengan sengaja, dan pengabdian kehidupan mereka dalam kasih kepada anak-

\footnotetext{
${ }^{2}$ Kitab Amsal 19:18; 22:6)

${ }^{3}$ John R.W. Stott, Seri Pemahaman dan Penerapan amanat Alkitab Masa Kini (Jakaerta : Yayasan Komunikasi Bina Kasih, 2000), 233

${ }^{4}$ J.L.CH. Abineno, Tafsiran Alkitab Surat Efesus (Jakarta : Gunung Mulia, 2012), 225
} 
anak mereka dengan hati yang penuh belas kasihan, kemurahan, kerendahan hati, kelemahlembutan, dan kesabaran (Kol. 3:12-14, 21). ${ }^{5}$

Benih iman ataupun sikap religius telah tersirat di dalam setiap anak, karena iman merupakan karunia Allah dan sudah dimiliki sejak anak itu lahir.Tuhan Yesus mengatakan bahwa anak adalah "yang empunya kerajaan Allah" (Lukas 18:16) dan "yang terbesar di dalam kerajaan Allah" (Matius 18:1).Oleh sebab itu, "Barang siapa menyesatkan salah satu dari anak-anak kecil ini yang percaya kepada-Ku, lebih baik baginya jika sebuah batu kilangan dikatakan pada lehernya lalu ditenggelamkan ke dalam laut" (Matius 18:6).Katakata Tuhan Yesus ini hendaknya membuat setiap orangtua beriman sadar bahwa tidaklah ringan peranan orangtua dalam mengembangkan ketergantungan, dan kepercayaan seorang anak kepada Allah.Selain itu, subur atau kerdilnya pertumbuhan benih iman ataupun sikap religius di dalam diri seorang anak sangat bergantung pula pada pengaruh lingkungan dimana anak itu tumbuh dan berkembang, sehingga Tuhan Yesus mengatakan "celakalah dunia dengan penyesatannya" (Matius 18:7), jadi lingkungan keluarga merupakan faktor utama yang mempengaruhi perkembangan iman maupun sikap religius seorang anak.Bantuan dari ibu, bapak, saudara-saudaranya yang lebih tua dirumah sangat dibutuhkan di dalam pendidikan iman ataupun sikap religius seorang anak. ${ }^{6}$

Keluarga merupakan tempat pendidikan pertama dan utama bagi anak.Pendidikan dalam keluarga sangat berperan dalam mengembangkan dan membentuk watak, karakter, kepribadian anak.Oleh karena itu, pendidikan karakter dalam keluarga perlu diberdayakan secara serius.Tugas dan tanggung jawab orangtua dalam keluarga terhadap pendidikan anak-anaknya lebih bersifat pembentukan watak serta moral mereka. ${ }^{7}$ Selanjutnya, keluarga juga merupakan suatu kelompok sosial yang bersifat langgeng berdasarkan hubungan pernikahan dan hubungan darah, jadi keluarga adalah tempat pertama bagi anak, lingkungan pertama yang memberi penampungan baginya, tempat anak akan memperoleh rasa aman. ${ }^{8}$

Perubahan nilai dalam masyarakat akan menimbulkan masalah bagi orangtua, terutama dalam membentuk tujuan perkembangan yang realitas bagi diri mereka dan anak-

${ }^{5}$ Donald C. Stamp, Alkitab Penuntun Berkelimpahan (Malang : Gandum Mas, 2000), 1994

${ }^{6}$ Alfons Sene, Iman yang Hidup (Jakarta : Komisi Kateketik KWI, 1999), 1.

${ }^{7}$ H. Fuad Ihsan, Dasar-Dasar Pendidikan (Jakarta : Rineka Cipta, 2008), 57-58

${ }^{8}$ Yulia Singgih D. Gunarsa, Asas-Asas Psikologi Keluarga Idaman (Jakarta : Gunung Mulia, 2009), 
anaknya. Sosialisasi makin disadari dan menjadi lebih sistematis karena anak sudah dapat berbicara, dan dengan bertambahnya umur maka terjadilah perubahan-perubahan dalam upaya mengubah dan membentuk tingkah laku anak.Anak perlu larangan terhadap perbuatan-perbuatan yang tidak baik, tidak layak, tidak pantas dilakuakan, supaya belajar menahan diri dan tidak melakukan perbuatan-perbuatan yang tidak baik.Anak perlu dipuji apabila melakukan perbuatan baik, mencapai prestasi, atau memperlihatkan sikap-sikap yang baik.Peranan orangtua dalam perkembangan anak, sebagai orangtua, mereka membesarkan, merawat, memelihara, dan memberikan anak kesempatan berkembang. Orangtua mengajarkan peraturan-peraturan, tata cara keluarga, menanamkan pedoman hidup bermasyarakat. Orangtua sebagai tokoh teladan, ditiru tingkah lakunya, cara berbicara. Orangtua juga mengawasi, memperhatikan, mengamati kelakuannya.Mereka mengawasi anak agar tidak melanggar peraturan di rumah maupun di luar lingkungan keluarga, selanjutnya hubungan orangtua dengan anak sebaiknya lebih terlihat adanya kehangatan.Tetapi di samping kehangatan dan sikap memberi kesempatan berkembang, perlu juga adanya sikap membatasi perilaku anak yang tidak sesuai dengan pola tingkah laku yang diinginkan oleh masyarakat umum.Untuk pembatasan perilaku, anak perlu teknik disiplin yang dilaksanakan secara konsisten. ${ }^{9}$

Proses tumbuh kembang seorang bayi menjadi seorang manusia dewasa merupakan suatu proses yang sangat menarik untuk diamati. Proses tumbuh kembang merupakan hasil interaksi dinamik antara keadaan "biologi" individu yang bersangkutan dan lingkungan di mana individu itu hidup. Jadi, peran orangtua bagi anak-anaknya sangatlah penting untuk perkembangan moral dan pertumbuhan rohaninya. ${ }^{10}$

Peranan orangtua menuntut untuk berbuat sesuatu bagi si anak.Orangtua tidak boleh menganut prinsip "Biarlah anak berkembang sendiri" atau menyerah dengan pernyataan, "Memang anak itu sudah mempunyai barkat menjadi anak nakal", dan seterusnya. Orangtua mempunyai tanggung jawab yang besar untuk kehidupan serta masa depan bagi anak-anaknya. ${ }^{11}$

\footnotetext{
${ }^{9}$ Ibid., 44-46

${ }^{10}$ Ismed Yusuf, Nadjmir, Eliyati, Aspek Kesehatan Jiwa Dalam Pembinaan dan Pengembangan Anak Balita (Forum Komunikasi Pembinaan dan Pengembangan Kesejahteraan Anak dan Kelompok Studi Kesehatan Jiwa Anak dan Remaja), 65

${ }^{11}$ Singgih D. Gunarsa, Psikologi Perkembangan (Jakarta : Gunung Mulia, 1992), 7
} 
Peranan orangtua untuk anaknya tidak hanya sekedar menginginkan anaknya cerdas, jenius, mendapat prestasi yang baik.Tetapi yang utama dan yang terutama adalah bagaimana orangtua menyadari bahwa peranan orangtua dalam pertumbuhan moral serta pertumbuhan iman bagi anak-anaknya sangatlah penting dan itulah yang menjadi tugas dan tanggung jawab bagi para orangtua. ${ }^{12}$

Hilderd Geertz mengatakan bahwa Keluarga sebagai kelompok sosial terkecil dan keluarga besar, mempunyai tugas menyiapkan anggotanya untuk dapat berhubungan secara sosial dengan dunia diluarnya. Orangtua sangat berperan aktif untuk pembentukan moral, sehingga ajaran yang diajarkan sejak kecil akan tertanam oleh sang anak dan akhirnya akan menjadi bekal untuk kehidupan seterusnya. ${ }^{13}$

Filsuf Inggris yang terkenal yang bernama John Locke (1632-1704) mengatakan bahwa pengalaman dan pendidikan bagian anak merupakan faktor yang paling menentukan dalam perkembangan anak.Isi kejiwaan anak ketika dilahirkan ibarat secarik kertas yang masih kosongartinya ketika anak dilahirkan masih belum mengerti apa-apa dan sangat dibutuhkan bimbingan utama dari orang tua.Locke mengatakan istilah "tabula rasa" untuk mengungkapkan pentingnya pengaruh pengalaman lingkungan hidup terhadap perkembangan anak.Anak adalah pribadi yang masih bersih dan peka terhadap rangsangan yang berasal dari lingkungan.Orangtua, karena itu sangat penting peranannya dalam mengisi secarik kertas kosong itu mulai dari bayi.Jadi, dalam filsuf ini dapat disimpulkan bahwa peranan orang tua sangat besar dan peranan itu dimulai sejak anak masih bayi. ${ }^{14}$

Keberadaan anak-anak adalah sesuatu hal yang sangat berharga.Mereka bukan hanya istimewa bahkan sangat penting.Anak-anak juga merupakan pribadi yang sangat penting.Selain disebut sebagai generasi penerus, anak-anak juga pribadi yang sangat penting dan berharga dihadapan Allah. Biasanya, sebagai anak orang percaya tetap berada di bawah bimbingan orangtua hingga mereka menjadi bagian dari kesatuan keluarga yang lain melalui pernikahan. Kewajiban yang penting dari "orangtua" ialah memberikan kepada anak mereka ajaran dan teguran yang termasuk pengasuhan Kristen.Orangtua harus

\footnotetext{
${ }^{12}$ Novita Tandy, Mengenal Tahap Tumbuh dan Berkembang Anak dan Masalahnya (Jakarta : Gunung Mulia, 2012), 3

${ }^{13}$ N.K. Atmadja Hadinoto, Keluarga Kristen Dalam Masyarakat Indonesia(Jakarta : Gunung Mulia, 1993), 9 16

${ }^{14}$ Singgih D. Gunarsa, Dasar dan Teori Perkembangan Anak (Jakarta : Gunung Mulia, 2008), 15-
} 
menjadi teladan dalam kehidupan dan perilaku Kristen, serta lebih mempedulikan keselamatan anak mereka daripada pekerjaan, profesi, pelayanan mereka di gereja atau kedudukan sosial mereka. ${ }^{15}$

Ada hal-hal yang mengkuatirkan adalah situasi di mana makin banyak anak-anak yang hidup dalam keluarga yang retak, keluarga yang penuh kekerasan dan banyak anakanak yang ditolak oleh keluarganya sehingga psikologi anak mengalami gangguan. Dalam keadaan seperti inilah yang membuat kehidupan anak bertumbuh secara moral dan agama menjadi dasar yang tidak penting bagi anak, belum lagi ditambah dengan kesibukan dari orangtua yang tahunya hanya bekerja saja tanpa mempedulikan kerohanian anaknya, orangtua menyerahkan pendidikan kerohanian anaknya sepenuhnya dengan gereja atau guru sekolah minggu, inilah tindakan yang dilakukan oleh para orangtua yang belum menyadari begitu pentingnya pendidikan rohani bagi anak-anaknya. Padahal setiap orang Kristen dipanggil untuk mengajar (Ulangan 6:6-7), untuk mendidik (Amsal 22:6), dan untuk membangun (Efesus 6:4) anaknya sedemikian sehingga anak tersebut mampu mengalami kehidupan yang berkelimpahan (Yohanes 10:10). ${ }^{16}$

Pelayanan dan pertumbuhan kerohanian anak adalah merupakan tugas dan tanggung jawab sepenuhnya sebagai orangtua, gereja dan guru-guru sekolah minggu hanya sebagai fasilitas pendukung tetapi yang berperan aktif adalah orangtua. ${ }^{17}$

Namun pada kenyataannya yang dijumpai oleh penulis, orangtua kurang menyadari peranannya sebagai orangtua dalam pertumbuhan rohani anak. Di lapangan penulis menemukan beberapa fakta yang terjadi bahwa masih ada beberapa orangtua yang belum menyadari tugas dan tanggung jawabnya sebagai peran utama untuk membantu pertumbuhan rohani anak, contohnya: orangtua melalaikan peranannya untuk mendidik, melatih, mengajarkan tentang kebenaran Alkitab, sehingga itu mempengaruhi moral yang buruk untuk sang anak dan akhirnya itu akan menjadi sebuah tindakan yang akan dilakukan oleh sang anak contohnya menjadikan sang anak moralnya kurang baik, suka melawan, meberontak kepada orangtua. Contoh lainnya pada waktu dewasa nantinya sang anak akan memilih pasangan hidupnya dengan lain iman akhirnya dengan mudah untuk

\footnotetext{
${ }^{15}$ Stephen Tong, Arsitek Jiwa (Surabaya : Momentum, 2003), 4

${ }^{16}$ Paul D. Meir M.D., Membesarkan Anak dan pengembangan Watak Secara Kristen, 58

${ }^{17}$ Ruth S. Kadarmanto, Tuntunlah Ke Jalan Yang Benar (Jakarta : BPK Gunung Mulia, 2011), 9
} 
meninggalkan iman demi teman hidup. Inilah sebabnya orangtua mempunyai peranan yang besar untuk membuat sang anak berhasil, baik iman dan pendidikan untuk masa depannya.

\section{PENTINGNYA PERAN ORANGTUA DALAM PERTUMBUHAN ROHANI ANAK MENURUT SURAT EFESUS 6:1-4}

Surat Efesus termasuk salah satu pembagian surat Perjanjian Baru yaitu surat penjara yang terdiri dari surat Efesus, surat Filipi, surat Kolose, dan surat Filemon.

Dalam pembahasan ini, penulis akan memaparkan rincian tentang surat Efesus. Surat Efesus merupakan salah satu puncak dalam penyataan Alkitabiah dan menduduki tempat yang unik di antara surat-surat Paulus.. ${ }^{18}$

Dalam bagian ini penulis mengeksegese beberapa kata penting untuk mendapatkan kajian yang mendalam sehingga dapat memahami "Pentingnya peran orang tua dalam pertumbuhan rohani anak menurut surat Efesus"

\section{Mengajar Anak Untuk Taat}

Kata "Taatilah" dalam bahasa Yunani menggunakan kata v́ $\alpha \kappa o v ́ \varepsilon \tau \varepsilon$ dari kata dasar

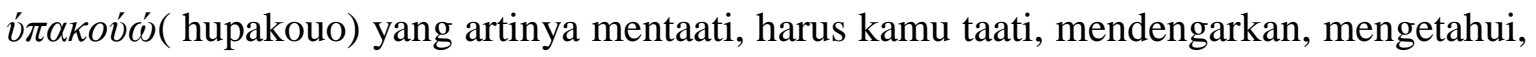
menuruti, menyerahkan diri. Memakai kasus (Verb 2 Plural Present Aktive Imperative). ${ }^{19}$ Kasus ini merupakan kata kerja orang kedua jamak yang terus aktif. Dalam New International Version(NIV) kata taatilah memakai kata "obey" yang memiliki arti mematuhi. ${ }^{20}$ Dari konteks secara keseluruhan dapat disimpulkan bahwa "Hupakouo" artinya tidak hanya sekedar mentaati tetapi juga mendengar sehingga dapat mengetahui dan menyerahkan diri. ${ }^{21}$ Dalam Alkitab Firman Allah yang hidup mengatakan bahwa anakanak, taatilah orang tuamu, karena Allah telah memberi wewenang atas kamu. ${ }^{22}$

Jadi sangat jelas dikatakan bahwa anak harus taat dan tunduk kepada orangtua sebab orangtua tidak hanya sekedar mengasuh, membimbing, menolong anak-anaknya melainkan orang tua telah di beri wewenang oleh Allah sendiri. Oleh sebab itu seorang anak harus mentaati orangtuanya, sebab firman Tuhan juga mengatakan bahwa ketika anak

\footnotetext{
${ }^{18}$ Donal C. Stamp, Alkitab Penuntun Berkelimpahan..., 1957

${ }^{19}$ Hasan Susanto, Perjanjian Baru Intelinier-Yunani Indonesia dan Konkordansi Perjanjian Bari Jilid I (Jakarta : Lembaga Alkitab Indonesia (LAI), 2010), 1044

${ }^{20}$ Ibid.

${ }^{21}$ Ibid.

${ }^{22}$ Oman Y. H, Firman Allah Yang Hidup Perjanjian Baru Dalam Bahasa Sehari-hari (Bandung : Kalam Hidup, 1976), 298
} 
taat kepada orangtua maka sesungguhnya Allah telah mewariskan kerajaan-Nya dan umur akan ditambahkan itu adalah janji Allah sendiri. Ini perintah Allah yang harus dilakukan.

\section{Mendidik Anak Tanpa Kekerasan}

Kata "Janganlah" dalam bahasa Yunani memakai kata v́ $\eta$ (me) yang artinya tidak,jangan, supaya jangan, apakah mungkin, jangan lagi.Memakai kasus (particle, negative). ${ }^{23}$ Kasus ini menunjukkan hal negative yang menegur untuk tidak dilakukan.Dalam Kamus Besar bahasa Indonesia (KBBI) kata janganlah artinya kata larangan, berarti tidak boleh. ${ }^{24}$ Dalam New International Version (NIV) kata janganlah memakai kata "do not" yang artinya jangan. ${ }^{25}$ Dalam hal ini kata "me" berarti menunjukkan suatu larangan yang tidak boleh dilakukan.

Jadi dalam hal ini bahwa orangtua jangan sampai membangkitkan amarah atau menimbulkan pertengkaran kepada sang anak, dalam setiap perkataan orangtua jangan sampai menimbulkan luka atau kebencian dalam hati sang anak.

\section{Pentingnya Peran Orangtua Dalam Mendidik}

Kata "didiklah" dalam bahasa Yunani memakai kata $\varepsilon \kappa \tau \rho \varepsilon \phi \varepsilon \tau \varepsilon$ dari kata dasar $\varepsilon \kappa \tau \rho \varepsilon \phi \omega$ (ekphero) yang artinya memberi makanan, mengasuh.Memakai kasus (verb second person plural present active imperative). ${ }^{26}$ Kasus ini merupakan kata kerja orang kedua jamak yang merupakan kata perintah yang harus dilakukan sekarang secara aktif.Dalam bahasa New Internasioanal Version (NIV) memakai kata "bring them up" artinya membawa. ${ }^{27}$ Dalam Kamus Besar Bahasa Indonesia (KBBI) kata "didiklah" memiliki arti memelihara dan memberi latihan. ${ }^{28}$ Dari konteks keseluruhan kata "ekphero" memiliki arti mengasuh, memelihara, dan memberi latihan.Artinya kewajiban orangtua untuk mendidik anaknya tidak sekedar mendidik tetapi dengan tekun mengasuh dan memelihara anaknya.

\footnotetext{
${ }^{23}$ Hasan Susanto, Perjanjian Baru Intelinier-Yunani Indonesia dan Konkordansi Perjanjian Bari Jilid I..., 1045

${ }^{24}$ John M. ecois, Hassen Shadily, Kamus Besar Bahasa Indonesia (KBBI) (Jakarta : Gramedia Pustaka Utama, 2007), 564 Jilid I..., 1045

${ }^{25}$ Hasan Susanto, Perjanjian Baru Intelinier-Yunani Indonesia dan Konkordansi Perjanjian Bari Jilid I..., 1045

${ }^{26}$ Hasan Susanto, Perjanjian Baru Intelinier-Yunani Indonesia dan Konkordansi Perjanjian Bari

${ }^{27}$ Ibid.

${ }^{28}$ John M. Ecois, Hassen Shadily, Kamus Besar Bahasa Indonesia..., 133
} 
Jadi kewajiban sebagai orangtua harus mendidik anak-anaknya, mendidik bukan hanya dalam artian untuk memperluas wawasan atau pengetahuan melainkan mendidik supaya si anak semakin hari semakin takut akan Tuhan, mendidik dalam artian membawa si anak dalam pengenalan akan Allah.

\section{Pentingnya Peran Orangtua Dalam Mengajar}

Kata "ajaran" dalam bahasa Yunani memakai kata $\pi \alpha l \delta \varepsilon i \alpha$ (paideia) yang artinya pendidikan.Memakai kasus (noun feminine singular dative). ${ }^{29}$ Kasus ini merupakan kata benda feminim dalam bentuk tunggal.Dalam bahasa New Internasional Version (NIV) memakai kata "training" artinya pelatihan. ${ }^{30}$ Dalam Kamus Besar Bahasa Indonesia kata ajaran arinya melatih, memarahi. ${ }^{31}$ Dalam konteks ini kata "paideia" artinya mendidik, melatih, dan marahi.Jadi fungsi orang tua tidak hanya mendidik melainkan melatih dalam hal kerohanian anak.Ajaran ini harus dilakuakn secara terus-menerus.

Jadi dalam hal ini dapat disimpulkan bahwa tindakan sebagai orang tua harus di wujudnyatakan dalam mengajari setiap anak-anaknya, mengajari dalam hal supaya anak tetap takut akan Tuhan. Mengajari supaya anak tetap percaya kepada Tuhan.Pengajaran itu harus dilakukan oleh orang tua dan di sampaikan kepada anak-anak mereka.

\section{Pentingnya Peran Orangtua Dalam Menasihati}

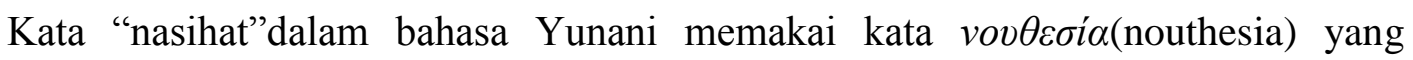
artinya nasihat, peringatan.Memakai kasus (noun feminine singular dative). ${ }^{32}$ Kasus ini merupakan kata benda feminim dalam bentuk tunggal. Dalam bahasa New Internasional Version (NIV) memakai kata "instruction" artinya intruksi. ${ }^{33}$ Dalam konteks ini kata "nouthesia" dapat diartikan bahwa peringatan atau memberi intruksi. Tidak sekadar peringatan biasa melainkan peringatan supaya semakin takut akanTuhan.Dalam Firman Allah Yang Hidup memberikan nasihat-nasihat berdasarkan Firman Tuhan. ${ }^{34}$

Jadi dalam hal ini kewajiban orangtua tidak hanya sekedar menasihati melainkan menasihati dalam ajaran Tuhan, memperkenalkan siapa Tuhan. Orangtua harus mampu

\footnotetext{
${ }^{29}$ Hasan Susanto, Perjanjian Baru Intelinier-Yunani Indonesia dan Konkordansi Perjanjian Bari

Jilid I..., 1045

${ }^{31}$ John M. ecois, Hassen Shadily, Kamus Besar Bahasa Indonesia..., 23

${ }^{32}$ Hasan Susanto, Perjanjian Baru Intelinier-Yunani Indonesia dan Konkordansi Perjanjian Bari Jilid I..., 1045

33 Ibid.

${ }^{34}$ Oman Y. H, Firman Allah Yang Hidup Perjanjian Baru Dalam Bahasa Sehari-hari..., 298
} 
memanfaatkan waktu sebaik mungkin untuk memberikan nasihat kepada anaknya, tidak mengenal jam, hari, tidak mengenal capek. Pada waktu istirahat, pada waktu duduk, pada waktu bermain orangtua mengambil bagian untuk menasihati anak dalam ajaran Tuhan, ajaran Tuhan supaya menjadikan anak semakin takut akan Tuhan.

\section{KAJIAN THEOLOGIS}

Penulis akan membahas dalam kajian theologis tentang peranan orangtua dalam pertumbuhan rohani anak, mendidik anak dengan disiplin, mendidik anak dengan pola pengajaran firman Tuhan, mendidik anak dengan pola keteladanan.

\section{Peranan Orangtua Dalam Pertumbuhan Rohani Anak}

Ikatan antara orangtua dan anak pada masa dini atau balita merupakan fondasi bagi hubungan keluarga selanjutnya, bahkan turut membentuk dasar-dasar keluarga baru yang akan dibentuk kelak. ${ }^{35}$ Oleh karena itu ikatan batin antara orangtua dan anak harus tetap dipertahankan untuk membentuk hubungan yang baik antara orangtua dan anak.

Orangtua dan anak hendaknya memiliki waktu untuk berkumpul yaitu untuk bermain dan belajar bersama-sama, dengan demikian orangtua dapat menceritakan tentang kebenaran-kebenaran Allah kepada anak-anaknya. ${ }^{36}$

Dengan demikian hubungan orangtua dengan anak-anaknya sebaiknya memiliki hubungan yang penuh dengan kehangatan dengan harapan anak memiliki rasa nyaman, aman dalam lingkungan keluarganya tetapi disamping kehangatan dan diberikan kesempatan untuk berkembang perlu juga membatasi sikap atau perilaku anak yang jika tidak sesuai dengan pola tingkah laku yang diinginkan masyarakat sekitarnya. Dengan memperhatikan perkembangan anak-anaknya orangtua akan menjadi semakin dekat sehingga akan memiliki hubungan yang baik dan hal itu akan mempengaruhi perkembangan anak selanjutnya.

\section{Mendidik Anak Dengan Pola Disiplin}

Kata disiplin merupakan kata serapan dari bahasa asing (Inggris) "discipline" dan bahasa Belanda "discipline" yang artinya belajar. Menurut Dogson disiplin adalah

\footnotetext{
${ }^{35}$ Yulia Singgih D. Gunarsa, Azaz-azaz Psikologi Keluarga Idaman ..., 43

${ }^{36}$ Joyce Coon, Rencana Allah Bagi Rumah Tangga Kristen (Bandung: Yayasan Kalam Kudus, 1990), 196
} 
mengajar. ${ }^{37}$ Didiplin juga memiliki definisi yaitu melatih melalui pengajaran dan pelatihan. Disiplin merupakan bagian dari proses berkelanjutan pengajaran atau pendidikan. ${ }^{38}$ Dengan demikian jika orangtua sedang mendisiplinkan anaknya maka orangtua sedang mengajar dan melatih anak-anaknya.

Dalam bukunya Sastrapratedja menjelaskan bahwa pendisiplinan dapat disebut sebagai salah satu proses pendidikan, dan pendidikan yang dimaksud bukanlah seperti pendidikan formal disekolah, namun lebih menekankan pada pendidikan nilai yang bersifat penanaman dan pengembangan nilai-nilai dalam diri seseorang yang menyangkut dengan aspek kepribadian, etika moral dan lain-lain yang semuanya dapat disebut nilai. ${ }^{39}$ Dengan demikian pendisiplinan adalah pola untuk menanam dan mengembangkan nilai-nilai moral pada seseorang.

\section{Mendidik Anak Dengan Pola Pengajaran Firman}

Dalam buku Surjantoro menjelaskan "Secara rohani anak-anak seperti kita membutuhkan air susu yang murni dan yang rohani supaya olenya kamu bertumbuh.... I Petrus 2:2. Firman Tuhan adalah makanan rohani yang lezat dan bergizi tinggi”" ${ }^{40}$ Dengan demikian pengajaran firman Tuhan sangat bermanfaat untuk pertumbuhan rohani anak. Surjantoro juga mengatakan:

Pertumbuhan rohani berhubungan dengan pergaulan bersama Tuhan yang terwujud dalam doa dan firman Tuhan melaui aktivitas rohani dalam keluarga, gereja (Sekolah Minggu). Orangtua yang telah diberkati oleh Tuhan Allah bersatu menjadi satu daging dan dipercayakan anak-anak kepadanya, diberikan hak istimewa untuk bertanggung jawab bagi pertumbuhan ini yang sebagai penatalayanan yang baik harus bisa memberikan jawab dari apa yang telah dipercayakan-Nya. ${ }^{41}$

Firman Tuhan adalah hukum dari Tuhan kepada setiap manusia, jika ajaran firman Tuhan ini disampaikan kepada anak, maka akan membuat seorang anak bertumbuh dewasa, memiliki perkembangan emiso dan social yang baik. Dengan demikian pengajaran tentang firman Tuhan harus diajarkan orangtua kepada anak karena sangat penting dalam kehidupan kerohanian anak.

\footnotetext{
${ }^{37}$ Singgih Gunarsa, Mendisplin Anak dengan Kasih sayang (Jakarta: Bpk Gunung Mulia, 1995), 81

${ }^{38}$ Sirinam S. Khalsa, Pengantar Disiplin Dan Harga Diri (Jakarta: Indeks, 2008), 10

${ }^{39}$ M. Sastrapratedja, Pendidikan Nilai Memasuki Tahun 2000, Penyunting: EMK Kawardi (Jakarta: Grasindo, 1993), 3 2001), 32

${ }^{40}$ Bagus Surjantoro, Membangun Keluarga Untuk Kemuliaan-Nya (Jakarta: Obor Mitra Indonesia, ${ }^{41}$ Ibid., 7
} 


\section{Mendidik Anak Dengan Pola Keteladanan}

Keteladanan dari orangtua sangat berperan penting dalam kehidupan rohani anakanak, karena cara yang termudah bagi seorang anak untuk belajar tentang kehidupan rohani yang menyenangkan adalah apabila ia sendiri menyaksikannya di dalam kehidupan orangtuanya sendiri. ${ }^{42}$ Kerohanian orangtua juga menentukan kerohanian anak-anaknya, karena mereka akan melihat bagaimana hubungan orangtuanya dengan Tuhan.

Dari pemaparan di atas penulis menyimpulkan bahwa sikap orangtua dalam memberi teladan kepada anak-anaknya sangat penting dan harus dilakukan, karena keteladanan orangtua memberi dampak yang besar bagi anak. Karena anak akan meniru dan mencontoh apa yang di dengar, yang dilihat dari sikapp orangtuanya.

\section{RANGKUMAN}

Mengajarkan perintah Allah tidak hanya untuk mengajar secara berulang-ulang tetapi juga harus melilitkan pada kedua tangan mereka sehingga firman Tuhan yang mengendalikan hidup mereka sehingga membuat rohani mereka semakin betumbuh di dalam Tuhan. Bangsa Israel memberikan teladan bagi setiap orangtua masa kini ketika mereka memberikan pengajaran kepada anka-anaknya. Di tengah situasi zaman yang sudah mengalami banyak perubahan, kecanggihan teknologi lebih banyak menarik perhatian anak-anak sekarang daripada hal-hal yang rohani menyadarkan orangtua betapa pentingnya mereka harus membekali anak-anaknya dengan pengajaran firman Tuhan, karena hanya firman Tuhan yang dapat menuntun setiap orang untuk hidup dalam kebenaran.

Sebagai orangtua dalam mendidik kerohanian anak-anaknya, orangtua harus memahami apa yang menjadi tanggung jawabnya sebagai orangtua yaitu berperan dalam perkembangan anak-anaknya. Tanpa keteladanan, pengajaran orangtua tidak akan bisa diserap oleh anak-anak. Orangtua tidak bisa berkata dan memberi perintah supaya anak rajin berdoa, rajin membaca firman Tuhan, rajin kegereja sementara orangtua tidak pernah melakukan semua yang diperintahkan kepada anaknya, maka jika anak yang tidak melihat keteladanan dari orangtuanya, maka anak tersebut bisa mencemooh orangtuanya.

\footnotetext{
${ }^{42}$ Stepen, Janet Bly, Ibu Yang Penuh Perhatian., 31
} 
Setiap orangtua bukan hanya sekedar mengajarkan firman Tuhan melainkan melakukannya juga, maka niscaya anak-anakpun akan ikut melakukan perbuatan yang dilakukan oleh orangtuanya. Dalam hal ini orangtua berperan aktif bagi pertumbuhan kerohanian anaknya, tidak hanya sebatas menyerahkan kepada gereja atau guru sekolah minggu saja, melainkan orangtua yang berperan aktif terlebih dahulu di dalamnya. 


\section{DAFTAR PUSTAKA}

R.W. Stott, John. (2000). Seri Pemahaman dan Penerapan amanat Alkitab Masa Kini, Jakarta : YKBK

L.CH. Abineno, J. (2012). Tafsiran Alkitab Surat Efesus, Jakarta: BPK Gunung Mulia.

C. Stamp, Donald. (2000). Alkitab Penuntun Berkelimpahan, Malang : Gandum Mas.

Sene, Alfons. (1999). Iman yang Hidup, Jakarta : Komisi Kateketik KWI

Fuad Ihsan, H. (2008). Dasar-Dasar Pendidikan, Jakarta: Rineka Cipta.

Singgih D. Gunarsa, Yulia. (2009). Asas-Asas Psikologi Keluarga Idaman, Jakarta: Gunung Mulia.

D. Gunarsa, Singgih. (1992). Psikologi Perkembangan, Jakarta: BPK Gunung Mulia.

(2008). Dasar dan Teori Perkembangan Anak, Jakarta : Gunung Mulia.

Tandy, Novita. (2012). Mengenal Tahap Tumbuh dan Berkembang Anak dan Masalahnya, Jakarta : Gunung Mulia.

K. Atmadja Hadinoto, N. (1993). Keluarga Kristen Dalam Masyarakat Indonesia, Jakarta : Gunung Mulia.

Tong, Stephen. (2003). Arsitek Jiwa, Surabaya : Momentum.

S. Kadarmanto, Ruth. (2011). Tuntunlah Ke Jalan Yang Benar, Jakarta : BPK Gunung Mulia.

Susanto, Hasan. (2010). Perjanjian Baru Intelinier-Yunani Indonesia dan Konkordansi Perjanjian Bari Jilid I, Jakarta: Lembaga Alkitab Indonesia (LAI).

Coon, Joyce. (1990). Rencana Allah Bagi Rumah Tangga Kristen, Bandung: Yayasan Kalam.

Gunarsa, Singgih. (1995). Mendisplin Anak dengan Kasih sayang, Jakarta: Bpk Gunung Mulia.

S. Khalsa, Sirinam. (2008). Pengantar Disiplin Dan Harga Diri, Jakarta: Indeks.

Sastrapratedja, M. (1993). Pendidikan Nilai Memasuki Tahun 2000, Penyunting: EMK Kawardi, Jakarta: Grasindo.

Surjantoro, Bagus. (2001). Membangun Keluarga Untuk Kemuliaan-Nya, Jakarta: Obor Mitra Indonesia. 